\title{
Development of a Compact System for the Determination of Lead Using a Liquid Core Waveguide and a Blue Diode as a Light Source
}

\author{
Tomoki Yabutani, ${ }^{* \dagger}$ Honami KuroKawa,* Yuka HaYashi,* Hiromichi Higuchi,* Yuki Iwata,* \\ Yuya HaShIZume, $*, * *$ Shuji WAda, $* * *$ Yukako HaYaSHI,* and Junko MotonaKa* \\ *Department of Chemical Science and Technology, Institute of Science and Technology, \\ The University of Tokushima, 2-1 Minamijosanjima, Tokushima 770-8506, Japan \\ **Taiho Pharmaceutical Co., Ltd., 224-2 Hiraishi Ebisuno, Kawauchicho, Tokushima 771-0194, Japan
}

\begin{abstract}
A simple and compact system was developed for the on-site analysis of lead in environmental water samples. The system consisted of a custom-made blue diode as a light source, a liquid core waveguide (LCW) as spectrophotometric cell and a compact UV-visible spectrometer. It weighed within $1.5 \mathrm{~kg}$ in total. Lead was detected using a spectrophotometric indicator reagent (TPPS: 5,10,15,20-tetraphenyl-21H,23H-porphinetetrasulfonic acid, disulfuric acid, tetrahydrate) after masking interfering ions by coprecipitation with magnesium hydroxide. With an increase in the length of the LCW cell, the detection limit of lead was almost linearly enhanced, and the linear calibration range was shifted to a lower concentration range. The detection limit of lead by using $100 \mathrm{~cm}$ of a LCW cell was $2 \mathrm{nmol} \mathrm{dm}{ }^{-3}$. The observed value $\left(9.6 \pm 0.4 \mu \mathrm{g} \mathrm{dm}^{-3}\right)$ of lead in a river-water reference material (JSAC 0302-3) with this system was in good agreement with the certified value $\left(9.9 \pm 0.2 \mu \mathrm{g} \mathrm{dm}^{-3}\right)$.
\end{abstract}

(Received March 8, 2010; Accepted March 19, 2010; Published April 10, 2010)

Lead is a common metal, which is largely consumed in industrial fields. In spite of strict controls by regulations for environmental and human health protection, there are some cases of health damage from lead exposure. ${ }^{1,2}$ Therefore, accurate and simple methods for its determination are required to monitor emission and exposure.

Highly sensitive and selective methods, such as inductively coupled plasma mass spectrometry (ICP-MS) and atomic absorption spectrometry (AAS), have been used for the determination of lead. ${ }^{3-5}$ However, these methods are unsuitable for in situ and simple analysis because of expensive prices, large size and high-running cost.

Light emission diodes (LED) are useful as a compact light source for spectrophotometric detection. Suzuki et al. have reported analytical methods using LED equipped spectrophotometric systems. ${ }^{6,7}$ A liquid core waveguide (LCW) results in an improvement of the sensitivity of UV-vis spectrometric analysis due to an increase in the cell length under Lambert-Beer's law. A Teflon AF 2400 has a low refractive index $(\mathrm{RI}=1.29)$, which is lower than that of water $(\mathrm{RI}=1.33){ }^{8-12}$ The light introduced into the liquid core of aqueous samples undergoes total internal reflection at the wall of the Teflon tube. Some analytical applications using both LED and LCW have been reported, ${ }^{13,14}$ however, there have not been total systems focused on USB-driven LED and LCW. A light-weight property and power supply through USB cable to a LED and LCW-UV system are very important to establish in situ compact analytical systems.

In the present study, we developed a compact system using a blue diode as a light source, a LCW cell and a compact

† To whom correspondence should be addressed.

E-mail: yabutani@chem.tokushima-u.ac.jp
UV-visible spectrometer for the determination of lead. A USB-driven blue diode was newly custom-made as a light source and its weight was $c a .60 \mathrm{~g}$. Furthermore, we combined the spectrophotometric detection of lead using 5,10,15,20tetraphenyl-21H,23H-porphinetetrasulfonic acid, disulfuric acid, tetrahydrate (TPPS) as a spectrophotomeric indicator reagent with this compact system. Although the TPPS has a large molecular absorption coefficient $\left(2.75 \times 10^{5}\right)$, the conventional method using TPPS and UV measurements with $1 \mathrm{~cm}$ of cell-length is inadequate to determine trace lead. ${ }^{15}$ The LCW technique used in this study can provide an improvement in the sensitivity when using TPPS. However, there is still a problem of severe interferences with some metal ions for the detection of lead used by TPPS. Thus, a simple pretreatment using a magnesium hydroxide coprecipitation method ${ }^{16}$ was used to eliminate interferences from concomitants in environmental water samples.

All reagents were of analytical grade. Purified water used throughout the present experiments was obtained from a Milli-Q purification system (Nihon Millipore Kogyo, Tokyo). Metal standard solutions were prepared by commercial standard solutions $\left(1000 \mathrm{mg} \mathrm{dm}^{-3}\right)$ of each element for atomic-absorption spectrometry, purchased from Kanto Chemicals and Wako Chemicals Co. Ltd. (Japan). A Ultrapur grade $3 \mathrm{~mol} \mathrm{dm}^{-3}$ $\mathrm{NaOH}$ solution from Kanto Chemicals was used in a masking experiment. A river-water reference material (JSAC 0302-3) issued from the Japan Society of Analytical Chemistry (Tokyo, Japan) for verifying this analytical method was purchased. An ICP-MS (ICPM-8500, Shimadzu, Kyoto, Japan) was partly used to check the concentrations of $\mathrm{Pb}$ and interfering ions in a study of the masking.

A typical analytical procedure of the determination of lead in water samples is described as follows. A 2-ml sample was taken 


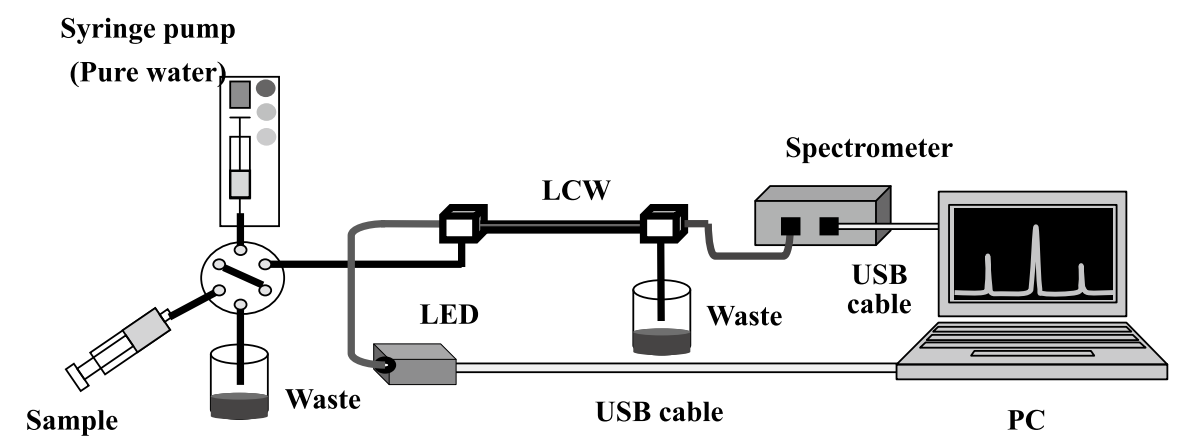

Fig. 1 Schematic diagram of the compact analytical system.

Table 1 Specifications of each part of the compact system

\begin{tabular}{llrr}
\hline \multicolumn{1}{c}{ Instrument } & \multicolumn{1}{c}{ Name } & Weight/g & Power supply \\
\hline Compact UV-visible & Ocean Optics USB2000 (wavelength can be scanned between 200 and & 250 & $9 \mathrm{~V}$ supplied by USB cable \\
spectrometer & $1100 \mathrm{~nm}$ ) & 5 & \\
LCW cell & Teflon AF 2400 tube (i.d. 0.8 mm, o.d. $1.0 \mathrm{~mm}$ ) & 60 & $5 \mathrm{~V}$ supplied by USB cable \\
LED & Blue LED (maximum wavelength, $470 \mathrm{~nm}$ ) & 1000 & $12 \mathrm{~V}$ supplied by AC $100 \mathrm{~V}$ \\
Syringe pump & Micro syringe pump (flow rate are changeable between 0.001 and $1000 \mu \mathrm{l}$ ) & 100 \\
\hline
\end{tabular}

in a centrifugation tube. Then, a $2-\mathrm{ml}$ portion of a $10 \mathrm{mg} \mathrm{dm}^{-3}$ magnesium solution and $0.2 \mathrm{ml}$ of a $1 \mathrm{~mol} \mathrm{dm}^{-3} \mathrm{NaOH}$ solution were added to the sample. The sample was filtrated by a $0.45-\mu \mathrm{m}$ PTFE disposable membrane filter (13HP045AN, ADVANTEC Co. Ltd., Osaka, Japan). A 0.5-ml portion of

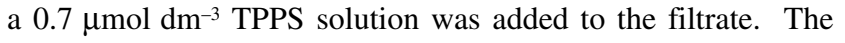
mixture solution was heated at $70^{\circ} \mathrm{C}$ for $5 \mathrm{~min}$ to accelerate the reaction of the $\mathrm{Pb}$-TPPS complex. The $1.0 \mathrm{ml}$ portion of sample solution was loaded into a sampling coil connected with a 6-way valve, and was then pumped to the LCW cell by a syringe pump. The LCW cell was washed with pure water prior to use. The concentration of lead in the analytical sample was estimated from a standard addition method for correcting for a slight loss of lead in the masking method.

A schematic diagram of the compact system is illustrated in Fig. 1. Specifications of the parts of the system are listed in Table 1. The LCW cell (Teflon AF 2400 tube; $1.0 \mathrm{~mm}$ o.d./0.8 mm i.d.; Biogeneral Co. Ltd., San Diego, CA, USA) was connected at the end of a blue diode, and the another end to a compact UV-visible spectrometer (USB 2000-UV-VIS, Ocean Optics Inc., FL, USA) by T-shape connectors. ${ }^{11}$ The blue LED component was custom-fabricated by Sato Denki (Tokushima, Japan). The total weight of the system, which consisted of a syringe pump, the LED, the LCW $(100 \mathrm{~cm})$, and a compact UV-visible spectrometer, was within $1.5 \mathrm{~kg}$. The amounts of electrical power consumption of the LED and the photometric detector were 9 and $5 \mathrm{~V}$, respectively. They could be supplied through USB cable from a PC. All of these parts and a lap-top PC could be packed in a normal bag for the lap-top PC $(44 \times 33 \times 16 \mathrm{~cm})$.

The Pb-TPPS complex has a large molecular absorption at $464 \mathrm{~nm} .^{15}$ The maximum wavelength of the Pb-TPPS was similar to that of a blue LED $(470 \mathrm{~nm})$. This result gave an advantage for the detection of Pb-TPPS by the LED.

In order to investigate the effect of the length of the LCW cell on the response, the linear range between the molecular absorption of the Pb-TPPS and the concentration was estimated. We used 10, 30, 68, and $100 \mathrm{~cm}$ lengths of the LCW cell.
Table 2 Analytical performances for the determination of lead by the LED-LCW spectrophotometic system

\begin{tabular}{|c|c|c|c|c|}
\hline Cell length $(\mathrm{cm})$ & 10 & 30 & 68 & 100 \\
\hline $\begin{array}{l}\text { Linear calibration range } \\
\left(\mathrm{mol} \mathrm{dm}^{-3}\right)\end{array}$ & $\begin{array}{r}5 \times 10^{-7}- \\
4 \times 10^{-6}\end{array}$ & $\begin{array}{r}2 \times 10^{-7}- \\
1 \times 10^{-6}\end{array}$ & $\begin{array}{r}1 \times 10^{-8}- \\
1 \times 10^{-7}\end{array}$ & $\begin{array}{r}5 \times 10^{-9}- \\
3 \times 10^{-8}\end{array}$ \\
\hline Correlation coefficient & 0.984 & 0.990 & 0.997 & 0.995 \\
\hline $\mathrm{DL}^{\mathrm{a}}\left(\mathrm{mol} \mathrm{dm}^{-3}\right)$ & $2 \times 10^{-8}$ & $1 \times 10^{-8}$ & $4 \times 10^{-9}$ & $2 \times 10^{-9}$ \\
\hline
\end{tabular}

a. Detection limit: the detection limits were obtained as the concentrations of lead corresponding to 3-times the standard deviation $(3 \sigma)$ of the absorbance observed with 10-times replicate measurements in a blank solution (TPPS $7.0 \times 10^{-6} \mathrm{~mol} \mathrm{dm}^{-3}$ ).

The analytical results are summarized in Table 2. The detection limit of lead was shifted to be a low concentration level along with an increase in the length of the LCW cell. The detection limit was $2 \mathrm{nmol} \mathrm{dm}^{-3}$ when using $100 \mathrm{~cm}$ of the cell length. In addition, a high linearity of the calibration range was observed. The equation of the calibration curve was Absorbance = $0.015 X-0.013$ (correlation coefficient $=0.995$ ), where $X$ is

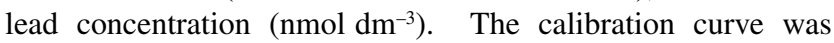
linear over the range from 5 to $30 \mathrm{nmol} \mathrm{dm}^{-3}$ for a $100-\mathrm{cm}$ cell. In the present work, the sensitivity estimated from the slope of the calibration curve was $c a$. 80-times higher than that in previous work reported by Itoh et al. when measuring the absorbance of the Pb-TPPS complex used with a normal $1 \mathrm{~cm}$ cell. ${ }^{15}$ The extension of the cell length in this system provided an improvement in the sensitivity.

It has been known that some metal ions interfered with the measurement of Pb-TPPS. ${ }^{15}$ We used a magnesium hydroxide coprecipitation method, which has been developed by the authors' group, for the selective and simple separation of lead to prevent interferences from concomitants. ${ }^{16}$ In previous research, it showed that $90 \%$ of lead could be recovered, and over $90 \%$ of interferents, including $\mathrm{Mn}, \mathrm{Co}, \mathrm{Cd}, \mathrm{Cu}$, and $\mathrm{Zn}$, were removed from the analytical samples. This method was 
Table 3 Analytical results for $\mathrm{Pb}$ in a river-water certified reference material (JSAC 0302-3) by the compact system with or without aid of $\mathrm{Mg}$ coprecipitation for the removal of interferents

\begin{tabular}{lcc}
\hline & \multicolumn{2}{c}{$\mathrm{Pb}$ conc./ $\mu \mathrm{g} \mathrm{dm}^{-3}$} \\
\cline { 2 - 3 } & Quantitative value $^{\mathrm{a}}$ & Guaranteed value \\
\hline Without Mg coprecipitation & $4.8 \pm 0.6$ & $9.9 \pm 0.2$ \\
With Mg coprecipitation & $9.6 \pm 0.4$ & $9.9 \pm 0.2$ \\
\hline
\end{tabular}

a. Mean \pm expanded uncertainty $(k=2)$.

applied in an analysis of a river-water reference material (JSAC 0302-3) sample. The results are given in Table 3. The result $9.6 \pm 0.4 \mu \mathrm{g} \mathrm{dm}^{-3}\left(46 \mathrm{nmol} \mathrm{dm}^{-3}\right)$ in the $\mathrm{Mg}$ coprecipitation method is in good agreement with the certified value $\left(9.9 \pm 0.2 \mu \mathrm{g} \mathrm{dm}^{-3}\right)$. On the other hand, the result without $\mathrm{Mg}$ coprecipitation was lower than the certified value due to interferences from concomitants. The detection limit of this system was sufficient to detect trace $\mathrm{Pb}$ around the standard values $\left(10 \mu \mathrm{g} \mathrm{dm}^{-3}\right)$ under the Japanese environmental protection law for water quality control.

The trace concentration of lead was determined by the system developed in this work. This system was light, compact in size and showed low electric power consumption. The detection limit with this system using the $100 \mathrm{~cm}$ cell was $2 \mathrm{nmol} \mathrm{dm}^{-3}$, which was similar compared to those of highly sensitive instruments, such as ICP-AES and AAS. For future prospects, a USB-driven pump should be designed in order to operate all parts of the system with an electric power supply through a USB cable from a PC.

\section{Acknowledgements}

The present study was partly supported by a young scientist fellowship from Institute of Science and Technology, the
University of Tokushima.

\section{References}

1. J. Yoshinaga, "Organometallic Compounds in the Environment", ed. P. Craig, 2002, Wiley, Chichester.

2. T. Yabutani, J. Motonaka, K. Inagaki, A. Takatsu, T. Yarita, and K. Chiba, Anal. Sci., 2008, 24, 791.

3. C. Vandecasteele and C. B. Block, "Modern Methods for Trace Element Determination", 1993, John Wiley and Sons, Ltd., Chichester.

4. H. Haraguchi, Bull. Chem. Soc. Jpn., 1999, 72, 1163

5. S. Akatsuki, R. Yamanouchi, Y. Nakamoto, K. Yoshizumi, M. Ogaki, T. Yabutani, Y. Hayashi, and J. Motonaka, Bunseki Kagaku, 2008, 57, 659.

6. Y. Suzuki, T. Aruga, H. Kuwahara, M. Kitamura, T. Kuwabara, S. Kawakubo, and M. Iwatsuki, Anal. Sci., 2004, 20, 975.

7. Y. Suzuki, T. Ito, T. Fukasawa, S. Kawakubo, and M. Iwatsuki, Bunseki Kagaku, 2005, 54, 291.

8. R. H. Byrne, W. Yao, E. Kaltenbacher, and R. D. Waterbury, Talanta, 2000, 50, 1307.

9. W. Yao and R. H. Byrne, Talanta, 1999, 48, 277.

10. R. D. Waterbury, W. Yao, and R. H. Byrne, Anal. Chim. Acta, 1997, 357, 99.

11. S. Wada, T. Kawatsu, Y. Hashizume, T. Yabutani, and J. Motonaka, Int. J. Modern Phys. B, 2006, 20, 4046.

12. H. Takiguchi, A. Tsubata, M. Miyata, T. Odake, H. Hotta, T. Umemura, and K. Tsunoda, Anal. Sci., 2006, 22, 1017.

13. Q. Li, K. J. Morris, P. K. Dasgupta, I. M. Raimundo, and H. Temkin, Anal. Chim. Acta, 2003, 479, 151.

14. J. Sivakumar, P. K. Dasgupta, D. K. Wolcott, G. D. Marshall, and D. C. Olson, Talanta, 1999, 50, 481.

15. J. Itoh, M. Yamahira, T. Yotsuyanagi, and K. Aomura, Bunseki Kagaku, 1976, 25, 781.

16. T. Yabutani, Y. Utsunomiya, Y. Kado, Y. Tani, H. Kishimoto, A. Fukuda, and J. Motonaka, Anal. Sci., 2006, 22, 1021. 